\title{
EXPOSURE TO ENVIRONMENTAL TOBACCO SMOKE IN THE WORKPLACE IN MACEDONIA: WHERE ARE WE NOW?*
}

\author{
Jordan MINOV ${ }^{1}$, Jovanka KARADŽINSKA-BISLIMOVSKA ${ }^{1}$, Kristin VASILEVSKA², Snežana \\ RISTESKA-KUC ${ }^{1}$, and Sašo STOLESKI ${ }^{1}$ \\ Institute of Occupational Health - WHO Collaborating Center for Occupational Health and GA²LEN \\ Collaborating Center ${ }^{1}$, Institute of Epidemiology and Biostatistics ${ }^{2}$, Skopje, Macedonia \\ Received in February 2008 \\ Accepted in May 2008
}

\begin{abstract}
To assess the prevalence and the level of exposure to environmental tobacco smoke (ETS) in the workplace after the enactment of the law restricting indoor smoking in Macedonia, we performed a cross-sectional, self-administered questionnaire study including 372 never-smoking workers recruited from six workplaces. We found a high prevalence of workers exposed to ETS in the workplace $(27.4 \%)$ with no significant difference between particular occupation groups. We found no significant difference in the prevalence of passive smokers in the workplace between this study and our study conducted before the law was enacted ( $31.5 \%$ vs. $27.4 \%, \mathrm{P}=0.324$ ). The prevalence of workers exposed to ETS for less than three hours a day was significantly lower than of passive smokers with longer exposure ( $28.4 \%$ vs. $71.6 \%, \mathrm{P}=0.038)$. The prevalence of workers exposed to ETS from less than 10 cigarettes smoked by coworkers per day was lower than the prevalence of workers with higher exposure, but statistical significance was not reached ( $37.9 \%$ vs. $62.1 \%, P=0.087$ ). Our findings indicate a high prevalence and a high level of exposure to ETS in the workplace, which calls for stricter adherence to smoking-free legislation or even the total ban of smoking in the workplace.
\end{abstract}

KEY WORDS: health effects, legislation, occupation, passive smoking, questionnaire

Involuntarily exposure to environmental tobacco smoke (ETS), also referred to as passive smoking and second-hand smoking (SHS), occurs wherever indoor smoking occurs: at home, in the workplaces, public places, and transportation. The amount of exposure depends on the number of smokers, the amount smoked, the size and ventilation characteristics of the indoor environment, and duration of exposure (1). ETS exposure can be assessed by measuring air nicotine and respirable suspended particle concentration or by measuring cotinine (i.e. a metabolite of nicotine specific for tobacco) in body fluids. In health effects

\footnotetext{
* The manuscript was partly presented at the 4th Croatian Congress on Occupational Health with International Participation, Dubrovnik, 8-11 November 2007
}

studies, ETS exposure is commonly assessed using questionnaires, because they are relatively cheap and make exposure assessment possible at different times and in different indoor environments (2).

ETS-related health reports date back to as early as the 1971 report of the United States Surgeon General (3). Since then many reports have indicated adverse health effect of exposure to ETS (4-6). They mirror those associated with active smoking (e.g. lung cancer and heart disease), but there are also other effects such as non-cancer respiratory effects that occur in sensitive subpopulations such as young children and asthma patients (7-9). On the other hand, some studies have indicated the importance of the location of exposure to ETS. Passive smoking in the workplace 
seems to be more associated with adverse respiratory effects than exposure to ETS at home $(10,11)$.

As adverse health effects of passive smoking were confirmed in many studies over the last decades, many countries worldwide have adopted laws to control tobacco smoking in indoor environments through bans or restrictions. Since 1 January 2006, Macedonia has adopted a law restricting indoor smoking in the official environments to well separated areas (12). To see the effects of this new legislation, we conducted a cross-sectional study to assess the prevalence and the level of exposure to environmental ETS in the workplace.

\section{METHODS}

\section{Study design}

A cross-sectional, self-administered questionnaire study was conducted at the Institute of Occupational Health, Skopje - WHO Collaborating Center and $\mathrm{GA}^{2}$ LEN Collaborating Center (IOH-WHO CC and GA2LEN CC) in the period May-June 2007, after having received ethics committee approval.

\section{Study population}

Study subjects were selected among workers (office workers, cleaners, textile workers, chemical industry workers, food processors, and shop assistants) who were periodically examined at the IOH-WHO CC and GA2LEN CC. All the workers who indicated that they had never smoked were asked to complete a questionnaire. Completion of the questionnaire was voluntary and anonymous; subjects were not required to attend the questionnaire sessions or to reveal their identity. All subjects gave their informed consent before entering the study.

\section{Questionnaire}

The self-administered, structured questionnaire covered demographic characteristics, education level, working history, and exposure to ETS in the workplace. It was adapted by our research team from a questionnaire used in the European Community Respiratory Health Survey (ECRHS) study on respiratory effects of passive smoking (10). Subjects with at least one smoker in the room where they worked were considered passive smokers in the workplace. Passive smokers in the workplace were then asked to estimate the number of hours per day they were exposed to co-worker's tobacco smoke (less or more than three hours) and the number of cigarettes smoked by co-workers per day (less or more than 10 cigarettes).

Completed questionnaires were placed into envelopes, sealed and returned to the research team. The subjects were reassured that no one other than designated researchers would have access to data identifying any of the subjects, and confidentiality was guaranteed.

\section{Statistical analysis}

Continuous variables were expressed as mean values with standard deviation (SD) and nominal variables as numbers and percentages. The chi-square test was used for testing difference in prevalence. A P-value below 0.05 was considered statistically significant. Statistical analysis was performed using the Statistical Package for the Social Sciences (SPSS) version 11.0 for Windows.

\section{RESULTS}

Of the 412 workers eligible to join the study, 384 (93.2\%) completed the questionnaire. Another 12 subjects who had incomplete answers were excluded. Therefore, this study included 372 subjects whose demographic characteristics are shown in Table 1.

The prevalence of workers exposed to ETS in the workplace was $27.4 \%$ There was no significant difference in the prevalence of passive smokers between men and women $(29.8 \%$ vs. $25.7 \%$, $\mathrm{P}=0.278$; chi square test).

The prevalence of workers exposed to ETS in different occupation groups varied from $25.9 \%$ in food processors to $32.8 \%$ in cleaners (Figure 1). There was no significant difference in the prevalence of passive smokers in the workplace between different occupation groups.

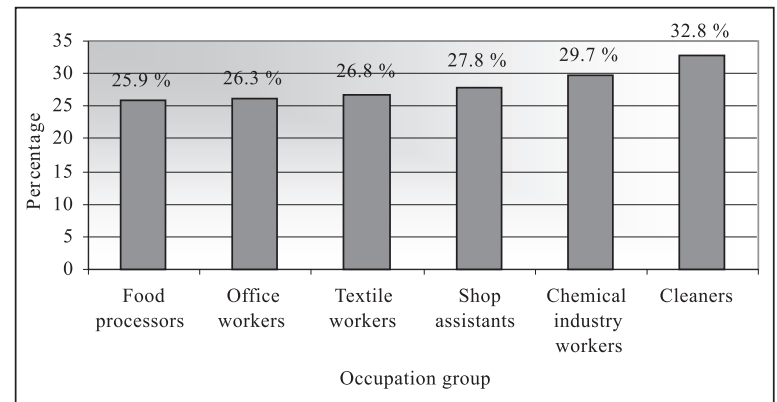

Figure 1 Distribution of passive smokers in the workplace by occupation group 
Table 1 Demographics of the study subjects

\begin{tabular}{|c|c|}
\hline & $\begin{array}{c}\text { Never-smoking workers } \\
(\mathrm{N}=372)\end{array}$ \\
\hline Men/Women ratio & 0.9 \\
\hline Age/years ${ }^{1}$ & $38.2 \pm 10.4(20-63)$ \\
\hline \multicolumn{2}{|l|}{ Occupation group } \\
\hline Office workers ${ }^{2}$ & $72(19.3 \%)$ \\
\hline Men/Women ratio & 0.8 \\
\hline Age/years ${ }^{1}:$ & $37.9 \pm 9.2(23-61)$ \\
\hline Cleaners $^{2}$ & $64(17.1 \%)$ \\
\hline Men/Women ratio & 0.5 \\
\hline Age/years ${ }^{1}:$ & $34.7 \pm 11.2(21-57)$ \\
\hline Textile workers ${ }^{2}$ & $68(18.3 \%)$ \\
\hline Men/Women ratio & 0.6 \\
\hline Age/years ${ }^{1}:$ & $40.3 \pm 13.1(20-62)$ \\
\hline Chemical industry workers ${ }^{2}$ & $51(13.7 \%)$ \\
\hline Men/Women ratio & 1.4 \\
\hline Age/years ${ }^{1}:$ & $39.1 \pm 8.4(24-54)$ \\
\hline Food processors ${ }^{2}$ & $54(14.5 \%)$ \\
\hline Men/Women ratio & 1.1 \\
\hline Age/years ${ }^{1}:$ & $41.3 \pm 10.8(25-63)$ \\
\hline Shop assistants ${ }^{2}$ & $63(16.9 \%)$ \\
\hline Men/Women ratio & 1.2 \\
\hline Age/years ${ }^{1}$ : & $38.0 \pm 11.3(23-59)$ \\
\hline \multicolumn{2}{|l|}{ Level of education } \\
\hline Higher education ${ }^{2}$ & $87(23.4 \%)$ \\
\hline Lower education $^{2}$ & $285(76.5 \%)$ \\
\hline
\end{tabular}

${ }^{1}$ Data are presented as mean \pm standard deviation and range

${ }^{2}$ Data are presented as the absolute number and percent of subjects

The prevalence of passive smokers in the workplace in this study was similar to the prevalence obtained in our earlier study on passive smoking carried out in 2005 (13) ( $P=0.324$; chi-square test) (Figure 2).

The prevalence of passive smokers in the workplace among subjects with higher and lower education was similar ( $P=0.291$; chi square test) (Figure 3).

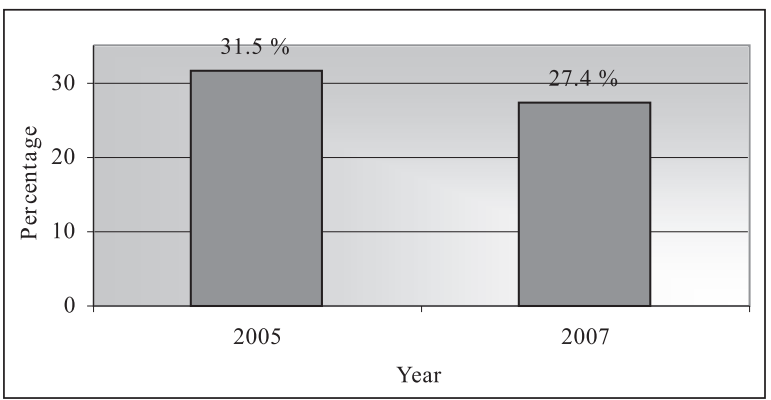

Figure 2 Prevalence of passive smokers in the workplace in the studies carried out in 2005 and 2007

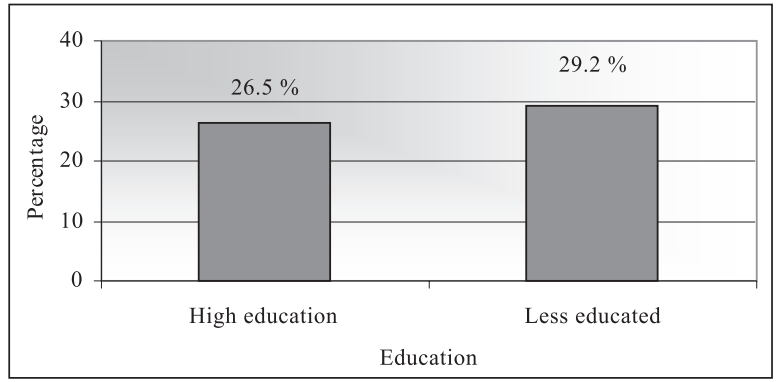

Figure 3 Distribution of passive smokers in the workplace by educational level

The prevalence of passive smokers whose coworkers smoked for less than three hours per day was significantly lower than the prevalence of those who were exposed to tobacco smoke for longer than 3 hours ( $P=0.038$; chi-square test) (Figure 4 ).

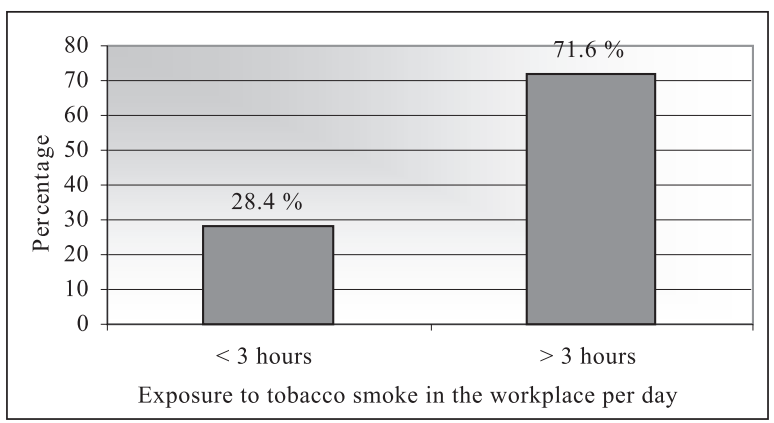

Figure 4 istribution of passive smokers in the workplace by number of hours of exposure to ETS per day

The prevalence of passive smokers in the workplace whose co-workers smoked less than 10 cigarettes per day was lower than the prevalence of those whose co-workers smoked more than 10 cigarettes per day, but the difference was not significant $(\mathrm{P}=0.087$; chisquare test) (Figure 5).

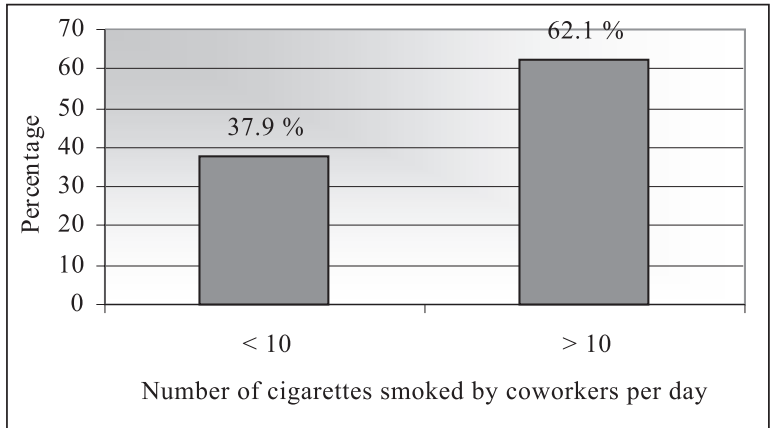

Figure 5 Distribution of passive smokers in the workplace by exposure to number of cigarettes smoked by co-workers per day

\section{DISCUSSION}

Many studies indicate that exposure to ETS in never-smokers is associated with various respiratory 
and non-respiratory symptoms and conditions, as well as with lower health-related quality of life, suggesting a dose-response relationship (14-16). Moreover, there is evidence that exposure to ETS is strongly associated with an increased incidence of respiratory symptoms and recent outpatient treatment even in current smokers (17). Stronger association between ETS in the workplace and adverse respiratory effects compared to household is probably due to the higher level of exposure to ETS in the workplace; people usually spend more time among a larger number of smokers at work than at home (18). On the other hand, despite controversial results of the studies that investigated joint effect of passive smoking in the workplace and specific workplace exposure, the role of such interaction in development of the respiratory impairment could not be excluded (19-21).

In this study we found a high prevalence of neversmoking workers exposed to ETS in the workplace with no significant difference between different occupation groups. Moreover, findings from our study carried out in 2005 and from this study (that is before and after the enactment of the law restricting indoor smoking) were similar, suggesting that non-smoking zones in the workplaces were not respected by smokers. Similarly, Alipour et al. (22), who studied respiratory effects of exposure to ETS, reported that despite smoking restriction in the workplace, ETS exposure was widespread among non-smoking French workers recruited from several workplaces. The prevalence of ETS exposure among the workers in their study was about $40 \%$, and they clearly indicated the need for a more efficient and appropriate legislation against ETS exposure in the workplace. Wakefield et al. (16), who studied exposure to ETS in the workplace among Australian non-smoking workers recruited from three workplaces with varying smoking policies, reported a significantly lower level of exposure to ETS and significantly lower prevalence of respiratory symptoms among office workers than among club and casino workers. Likewise, Mulcahy et al. (23), who studied second-hand smoke exposure in hotel workers following the Irish smoking ban, reported that passive smoking and associated risks were significantly reduced, but not totally eliminated. Compliance with the law was also reported by Farelly et al. (24) who studied changes in hospitality workers' exposure to ETS in the workplace after the implementation of
New York's smoke-free law that prohibits smoking in all workplaces.

In a longitudinal study with a follow-up period of 8.8 years conducted in 12 European countries, Australia, and the USA, Janson et al. (25) reported an $18.4 \%$ drop in passive smoking. These authors also found that people with a lower education level were more than twice as likely to become exposed to ETS than those with higher education level, and suggested that anti-smoking strategies should be targeted primarily at people with less skilled occupation groups. This was not confirmed by our study, as we found a similar prevalence of exposure to ETS in the workplace between subjects with higher and lower educational level. In other words, anti-smoking strategies in our country should targeted all workers and all occupation groups.

Measured by the number of hours of exposure per day and the number of cigarettes smoked by co-workers per day, the level of exposure to ETS among exposed workers in our study was high. These findings are of special importance, as there is consistent evidence of a dose-dependent risk of adverse respiratory effects caused by exposure to ETS in the workplace, the level of which is measured by hours per day and/or number of cigarettes per day $(17,26,27)$.

There were some limitations to our study which should be taken into account when interpreting the results. First, it included a relatively small group. Second, the study carried out in 2005 was performed with a different study group as we were not able to perform a cohort study due to the turnover of the workers from some occupation groups, which should be taken into consideration when comparing results the from the previous and this study. The strength of this study is that it investigated both the frequency and the level of exposure to environmental ETS in the workplace, and that it included subjects from different occupations.

In conclusion, our findings indicated high prevalence and level of exposure to environmental ETS in the workplace among never-smoking workers recruited from different workplaces. We propose stricter implementation of the current law restricting indoor smoking, or the total ban of smoking in the workplace in order to prevent adverse health effects of passive smoking and to create a new non-smoking culture in the workplace. 


\section{REFERENCES}

1. Chan-Yeung M, Dimich-Ward H. Respiratory health effects of exposure to environmental tobacco smoke. Respirology 2003;8:131-9.

2. Jaakkola MS, Jaakkola JJK. Assessment of exposure to environmental tobacco smoke. Eur Respir J 1997; 10:2384-97.

3. US Department of Health Education and Welfare (US DHEW). The health consequences of smoking. A report of the Surgeon General (DHEW Publication No. HSM 73-8704). Washington (DC): US Government Printing Office; 1971.

4. US Environmental Protection Agency (US EPA). Respiratory health effects of passive smoking: lung cancer and other disorders. Smoking and tobacco control monograph No. 4. NIH Publication no. 933605. Bethesda (MD): US Department of Health, Public Health Service, National Institute of Health; 1993.

5. California Environmental Protection Agency (CEPA). Health effects of exposure to environmental tobacco smoke. Sacramento (CA): Office of Environmental Health Hazard Assessment; 1997.

6. Scientific Committee on Tobacco and Health. Report of the scientific committee on tobacco and health. 011322124X. London: HMSO, The Stationery Office London; 1998.

7. World Health Organization Division on Noncommunicable Disease Tobacco Free Initiative. International consultation on Environmental Tobacco Smoke (ETS) and child health. Consultation Report. Geneva: WHO; 1999.

8. Vlaski E, Hristova M, Nikolovski Lj, Seckova L, Kostovski A, Sazdovski A, Dimitrievska D. Effect of prenatal and postnatal passive smoking on total serum IgE level and allergic sensitization. Mac J Med 1998;44:49-56.

9. Lannero E, Wickman M, van Hage M, Bergström A, Pershagen G, Nordvall L. Exposure to environmental tobacco smoke and sensitisation in children. Thorax 2008;63:172-6.

10. Janson C, Chinn S, Jarvis D, Zock JP, Toren K, Burney P; European Community Respiratory Health Survey. Effects of passive smoking on respiratory symptoms, bronchial responsiveness, lung function, and total serum IgE in the European Community Respiratory Health Survey: a cross-sectional study. Lancet 2001;358:2103-9.

11. Simoni M, Baldacci S, Puntoni R, Pistelli F, Farschi S, Lo Presti E, Pistelli R, Corbo G, Agabiti N, Basso S, Matteelli G, Di Pede F, Carozzi L, Forastiere F, Viegi G. Respiratory symptoms/diseases and environmental tobacco smoke (ETS) in never smoker Italian women. Respir Med 2007;101:531-8.

12. Law for protection from smoking. Official Gazette of R. Macedonia No 37/05.

13. Minov J, Karadžinska-Bislimovska J, Vasilevska K,
Stoleski S. Smoking status in exposed and unexposed workers. Mak med pregled 2006;60:128.

14. Gilmour MI, Jaakkola MS, London SJ, Nel AE, Rogers CA. How exposure to environmental tobacco smoke, ourdoor air pollutants, and increased pollen burdens influences the incidence of asthma. Environ Health Protect 2006; 114:627-33.

15. Bridevaux PO, Cornuz J, Gaspoz JM, Burnand B, Ackermann-Liebrich U, Schindler C, Leuenberger P, Rochat T, Gerbase MW; SAPALDIA Team. Secondhand smoking and health-related quality of life in never smokers: results from the SAPALDIA cohort study 2. Arch Intern Med 2007;167:2516-23.

16. Wakefield M, Cameron M, Inglis G, Letcher T, Durkin S. Secondhand smoke exposure and respiratory symptoms among casino, club, and office workers in Victoria, Australia. J Occup Environ Med 2005;47:698703.

17. Lam TH, Ho LM, Hedley AJ, Adab P, Fielding R, McGhee SM, Leung GM, Aharonson-Daniel L. Secondhand smoke and respiratory ill health in current smokers. Tob Control 2005;14(5):307-14.

18. Lam TH, Ho LM, Hedley AJ, Peymane A, Fielding R, McGhee S, Aharonson-Daniel L. Environmental tobacco smoke exposure among police officers in Hong Kong. JAMA 2000;284:756-63.

19. Ho SY, Lam TH, Chung SF, Lam TP. Cross-sectional and prospective associations between passive smoking and respiratroy symptoms at the workplace. Ann Epidemiol 2007;17:126-31.

20. Minov J, Karadzinska-Bislimovska J, Vasilevska K, Risteska-Kuc S, Stoleski S. Bronchial hyperresponsiveness in workers exposed to organic dusts: effect of smoking. Allergy Hypersensitivity Asthma 2006;4:11-20.

21. Mijakoski D, Karadzinska-Bislimovska J, Minov J, Trajceva L, Ezova N, Risteska-Kuc S, Stoleski S. Nasal symptoms in female cleaners: relation to respiratory symptoms, bronchial hyperresponsiveness, and duration of exposure. Eur Respir J 2007;30:154.

22. Alipour S, Deschamps F, Lesage F-X. Effects of environmental tobacco smoke on respiratory symptoms and pulmonary function. Inhal Toxicol 2006;18:569-73.

23. Mulcahy M, Evans DS, Hammond SK, Repace JL, Byrne M. Secondhand smoke and risk following the Irish smoking ban: an assessment of salivary cotinine concentrations in hotel workers and air nicotine levels in bars. Tob Control 2005; 14:384-8.

24. Farelly MC, Nonnemaker JM, Chou R, Hyland A, Peterson KK, Bauer UE. Changes in hospitality workers' exposure to secondhand smoke following the implementation of New York's smoke-free law. Tob Control 2005;14:236-41.

25. Janson C, Künzli N, de Marco R, Chinn S, Jarvis D, Svanes C, Heinrich J, Jögi R, Gislason T, Sunyer J, 
Ackermann-Liebrich U, Anto JM, Cerveri I, Kerhof M, Leynaert B, Luczynska C, Neukrich F, Vermiere P, Wjst M, Burney P. Changes in active and passive smoking in the European Community Respiratory Health Survey. Eur Respir J 2006;27:517-24.

26. Xu X, Li B. Exposure-response relationship between passive smoking and adult pulmonary function. Am J Respir Crit Care Med 1995;151:41-6.
27. Pilkington PA, Gray S, Gilmore AB. Health impact of exposure to second hand smoke (SHS) amongst a highly exposed workforce: survey of London casino workers. BMC Public Health 2007;7:257. 


\section{Sažetak}

\section{IZLOŽENOST AMBIJENTALNOMU DUHANSKOMU DIMU NA RADNOME MJESTU U MAKEDONIJI: KAKO SADA STOJIMO?}

Ovo je ispitivanje obuhvatilo 372 radnika na šest različith radnih mjesta koji nikad nisu pušili kako bi se procijenila zastupljenost osoba izloženih duhanskomu dimu na radnome mjestu i razina njihove izloženosti nakon zakonskih ograničenja pušenja u zatvorenim prostorijama u Makedoniji. Ispitivanje je provedeno s pomoću upitnika koji su radnici ispunjavali sami. Utvrdili smo visoku zastupljenost radnika izloženih ambijentalnomu duhanskomu dimu na radnome mjestu $(27,4 \%)$ te nisu zamijećene statistički značajne razlike među zanimanjima. Nisu uočene značajne razlike između zastupljenosti pasivnih pušača na radnome mjestu u ovome ispitivanju i u našem ranijem ispitivanju, kada još nije na snagu stupio zakon o ograničenju pušenja ( $31,5 \%$ naprema $27,4 \%, P=0,324)$. Zastupljenost radnika izloženih ambijentalnomu duhanskomu dimu ne dulje od tri sata na dan bila je statistički značajno niža negoli onih čija je izloženost trajala duže (28,4 \% naprema $71,6 \%, P=0,038)$. Zastupljenost radnika koji su bili izloženi dimu kolega koji su pušili manje od 10 cigareta na dan bila je niža negoli onih s većom izloženosti, ali razlika nije bila statistički značajna (37,9 \% naprema $62,1 \%, P=0,087)$. Naši rezultati potvrđuju da i dalje postoje visoka zastupljenost izloženih radnika i visoke razine izloženosti ambijentalnomu duhanskomu dimu na radnome mjestu, što upućuje na potrebu uvođenja strožih zakona o zabrani pušenja.

KLJUČNE RIJEČI: pasiuno pušenje, upitnik, zakonodaustuo, zanimanje, zdraustueni učinci

\section{CORRESPONDING AUTHOR:}

Jordan B. Minov, MD, PhD

Department of Cardiorespiratory Functional Diagnostics Institute of Occupational Health - WHO Collaborating Center and GA2LEN Collaborating Center II Makedonska Brigada 43, 1000 Skopje, R. Macedonia E-mail:minovj@hotmail.com 